\title{
Modelling Hydrodynamic Impacts of Sea-Level Rise on Wave-Dominated Australian Estuaries with Differing Geomorphology
}

\author{
Kristian Kumbier*, Rafael C. Carvalho and Colin D. Woodroffe ${ }^{\mathbb{D}}$ \\ School of Earth and Environmental Sciences, University of Wollongong, Wollongong 2522, Australia; \\ rafaelc@uow.edu.au (R.C.C.); colin@uow.edu.au (C.D.W.) \\ * Correspondence: kak609@uowmail.edu.au; Tel.: +61-432-595-813
}

Received: 20 April 2018; Accepted: 31 May 2018; Published: 5 June 2018

\begin{abstract}
Sea-level rise (SLR) will affect the hydrodynamics and flooding characteristics of estuaries which are a function of the geomorphology of particular estuarine systems. This study presents a numerical modelling of coastal flooding due to drivers such as spring-tides, storm surges and river inflows and examines how these will change under sea-level increases of $0.4 \mathrm{~m}$ and $0.9 \mathrm{~m}$ for two estuaries that are at different geomorphological evolutionary stages of infill. Our results demonstrate that estuarine response to SLR varies between different types of estuaries, and detailed modelling is necessary to understand the nature and extent of inundation in response to SLR. Comparison of modelling results indicates that floodplain elevation is fundamental in order to identify the most vulnerable systems and estimate how inundation extents and depths may change in the future. Floodplains in mature estuarine systems may drown and experience a considerable increase in inundation depths once a certain threshold in elevation has been exceeded. By contrast, immature estuarine systems may be subject to increases in relative inundation extent and substantial changes in hydrodynamics such as tidal range and current velocity. The unique nature of estuaries does not allow for generalisations; however, classifications of estuarine geomorphology could indicate how certain types of estuary may respond to SLR.
\end{abstract}

Keywords: inundation; coastal flooding; estuarine geomorphology; hydrodynamic modelling; barrier estuary; Australia

\section{Introduction}

The rise in global mean sea level (GMSL) and its expected consequences are undoubtedly one of the greatest challenges coastal communities are facing in the 21st century. The response of different coast types such as beaches, rocky shorelines, deltas or estuaries will be dynamic and include changes in hydrodynamics, coastal geomorphology and coastal ecology [1]. The fifth assessment report (AR5) of the Intergovernmental Panel on Climate Change (IPCC) indicates that average rises in GMSL (up to $0.82 \mathrm{~m}$ for RCP8.5) may differ from regionalised sea-level rise (SLR) projections [2]. More recent studies on GMSL reconstructions and satellite altimetry measurements confirm anticipated increases in sea level [3,4], whereas studies with an emphasis on icesheet contribution to SLR estimate that the rise in GMSL could exceed $2 \mathrm{~m}$ by 2100 [5,6]. Projections of SLR for the Australian coastline are similar to GMSL projections [7], even though regionalised studies for Australia indicate that SLR exhibits significant regional differences [8].

The consequences of SLR for coastal areas include immediate effects such as submergence, increased flooding and associated salt water intrusion of surface waters, as well as long-term effects such as increased erosion, changes in coastal ecosystems such as saltmarsh and mangrove habitats, 
and effects on tidal dynamics [9-13]. Estuarine environments may change considerably as the morphology of low-lying floodplains makes them particularly vulnerable to increased inundation by tides and storm surges. Assessing these changes is of great importance as many people live along estuarine shorelines and likely experience changes such as more frequent inundation, so-called nuisance flooding [14], or water backwashing up storm water drains. In addition, some estuaries are likely to experience a coincidence of coastal flooding with riverine discharge, so called compound flooding [15-17].

While bathtub models may be used to map flooding in certain estuarine environments [18], their application to assess estuarine response to SLR appears to be limited, because dynamics such as changes in tidal range or current velocity cannot be analysed. Bathtub models assume areas lower than a certain elevation to be inundated utilizing elevation data and a geographic information system (GIS) [19,20], but physical processes such as bottom friction or transfer of momentum are not considered. As the response of estuaries to SLR includes also changes in tidal range and current velocity, and responses appear to be more dynamic than bathtub models of SLR predict [21]; analysis of estuarine response to SLR requires detailed investigation using hydrodynamic modelling in order to assess changes in tidal range, current velocity, inundation extent or inundation depth. Estuarine response to SLR has been the focus of many studies [12,13,22-24]. Prandle and Lane [23] assessed how tide-dominated estuaries in the UK adapt to SLR and river flow using vulnerability indices. Yang et al. [24] investigated estuarine response to river flow and SLR under future climate change and land use changes in the Snohomish River, USA, using a coupled hydrologic-hydrodynamic model. Their simulations suggest that average water depth in inundated areas increases linearly with SLR, but at a slower rate than on the open coast, while average salinity in inundated areas increases linearly with SLR. Lee et al. [12] investigated tidal response to SLR in two coastal-plain estuaries in the USA, Chesapeake Bay and Delaware Bay, using the unstructured-grid finite volume Coastal ocean model (FVCOM) and hypothetical adaptation options (sea walls). Their simulations indicate a non-linear tidal response to SLR and a reduction in tidal range in up-stream locations due to tidal energy dissipation through inundation of low-lying areas. However, if inundation was restricted by sea walls, tidal range increased. Du et al. [13] assessed the tidal response to SLR for idealised and realistic estuaries (Chesapeake Bay and subestuaries) of different geomorphology using the semi-implicit cross-scale hydroscience integrated system model (SCHISM). Their simulations indicate that tidal response to SLR is spatially uneven and varies among different estuaries. While estuaries with a narrow channel and large floodplain are likely to experience decreased tidal ranges under high SLR, those with comparatively steep banks may experience an increase in tidal range.

However, none of the studies above compared estuarine response to SLR in wave-dominated barrier estuaries at different evolutionary stages. There are numerous estuaries along the wave-dominated coast of southeast Australia, which have been classified into several types and differ in terms of their geomorphological evolution [25]. Immature estuarine systems are incompletely infilled with sediments, whereas estuaries of mature evolutionary stage have been almost completely infilled with sediments. Whereas immature estuaries may experience considerable changes due to SLR, more mature estuaries that have developed broad alluvial floodplains may be particularly vulnerable to more frequent inundation when riverbank levees are overtopped or breached. A modelling study by Watterson et al. [22] in Lake Macquarie, an immature wave-dominated barrier estuary in central New South Wales (NSW), indicated a doubling of tidal range in response to SLR of $0.91 \mathrm{~m}$. Hydrodynamic modelling can indicate the vulnerability of settlements and infrastructure to SLR in and around estuaries and contribute to studies of biophysical vulnerability of estuaries as presented by Rogers and Woodroffe [26].

This study investigates estuarine response to SLR in two wave-dominated barrier estuaries at different infilling stage (youthful and mature) by determining changes in inundation extent, inundation depth, and changes in the underlying hydrodynamics such as tidal ranges and current velocities, using hydrodynamic modelling. Measurements of tidal gauges and river discharge for 
a specific storm event were analysed to create model forcing data sets representing spring-tide, storm-tide and extreme river discharge conditions. These inputs were combined to model inundation extents, inundations depths, tidal ranges and current velocities for present day conditions as well as for SLR increases of $+0.4 \mathrm{~m}$ and $+0.9 \mathrm{~m}$.

\section{Study Sites}

Lake Illawarra and the Shoalhaven Estuary are located approximately $80 \mathrm{~km}$ and $120 \mathrm{~km}$ south of Sydney on the wave-dominated microtidal southeast coast of Australia. Tides along the coastline are semi-diurnal with a significant diurnal inequality. Both estuaries have been categorized as wave-dominated barrier estuaries [25], even though they are at different evolutionary stage and display contrasting hydrodynamics. Barrier estuaries occur on wave-dominated coastlines and are separated from the open ocean by a sandy barrier. The opening of these estuaries comprises a mouth that can be temporarily sealed by a wave-generated berm on smaller systems, referred to as an intermittent entrance [27,28]. Mature wave-dominated barrier estuaries are defined by a channelised river that is surrounded by broad alluvial floodplains, whereas immature or youthful systems consist of a lake-like water body [25].

Whereas Lake Illawarra is at an immature infilling stage and characterised by a large water body that is bordered by comparatively narrow and small floodplains located around the main tributaries Mullet Creek and Macquarie Rivulet, the Shoalhaven Estuary has infilled its proto-lake with sediments over the past 6000 years [29] and is characterised nowadays by broad low-lying floodplains located mainly around Broughton Creek and south of the Shoalhaven River. The tidal regime of the Shoalhaven Estuary is charactersied by a tidal range of approximately $1.5 \mathrm{~m}$ at Crookhaven Heads during spring tides with only limited tidal attenuation $(0.2 \mathrm{~m})$ upstream towards Nowra. The highest tides of the year (HHWSS $=$ highest high water summer solstice) reach approximately $0.95 \mathrm{~m}$ above MSL at the entrance in Crookhaven Heads [30]. In Lake Illawarra the tidal regime is defined by a tidal range of approximately $1.0 \mathrm{~m}$ at the entrance gauge with severe attenuation $(0.8 \mathrm{~m})$ once the tidal wave passes the entrance channel. The highest tides of the year (HHWSS) reach approximately $0.66 \mathrm{~m}$ above MSL at the entrance [30] and cause a pumping of sea water into the lake, so called spring tidal pumping [31]. Riverine flooding highly influences the lower Shoalhaven Estuary and causes inundation of the floodplain due to the comparatively large catchment area $\left(7000 \mathrm{~km}^{2}\right)$ of the estuary. This contrasts with Lake Illawarra, where few peripheral areas are flooded, even though the two tributaries (of 75 and $100 \mathrm{~km}^{2}$ catchment area) have been shown to respond to high discharge as well [18]. Both estuarine systems have been modified in the past. The Shoalhaven River has been redirected towards Crookhaven Heads with the construction of Berry's Canal in 1822 and in consequence the former opening at Shoalhaven Heads has transformed into an intermittent entrance that only breaches during the largest storm events [32]. At Lake Illawarra the formerly intermittent entrance was stabilized and permanently opened through construction of training walls in 2001 and 2007. Figure 1 illustrates the floodplain topography of both study sites given in metres relative to Australian height datum (AHD), which approximates mean sea level (MSL). Blue areas represent water at MSL whereas green areas $(<1 \mathrm{~m})$ represent mostly intertidal areas which are subject to regular inundation by the tide, even though several floodgates in the Shoalhaven Estuary restrict regular inundation. 


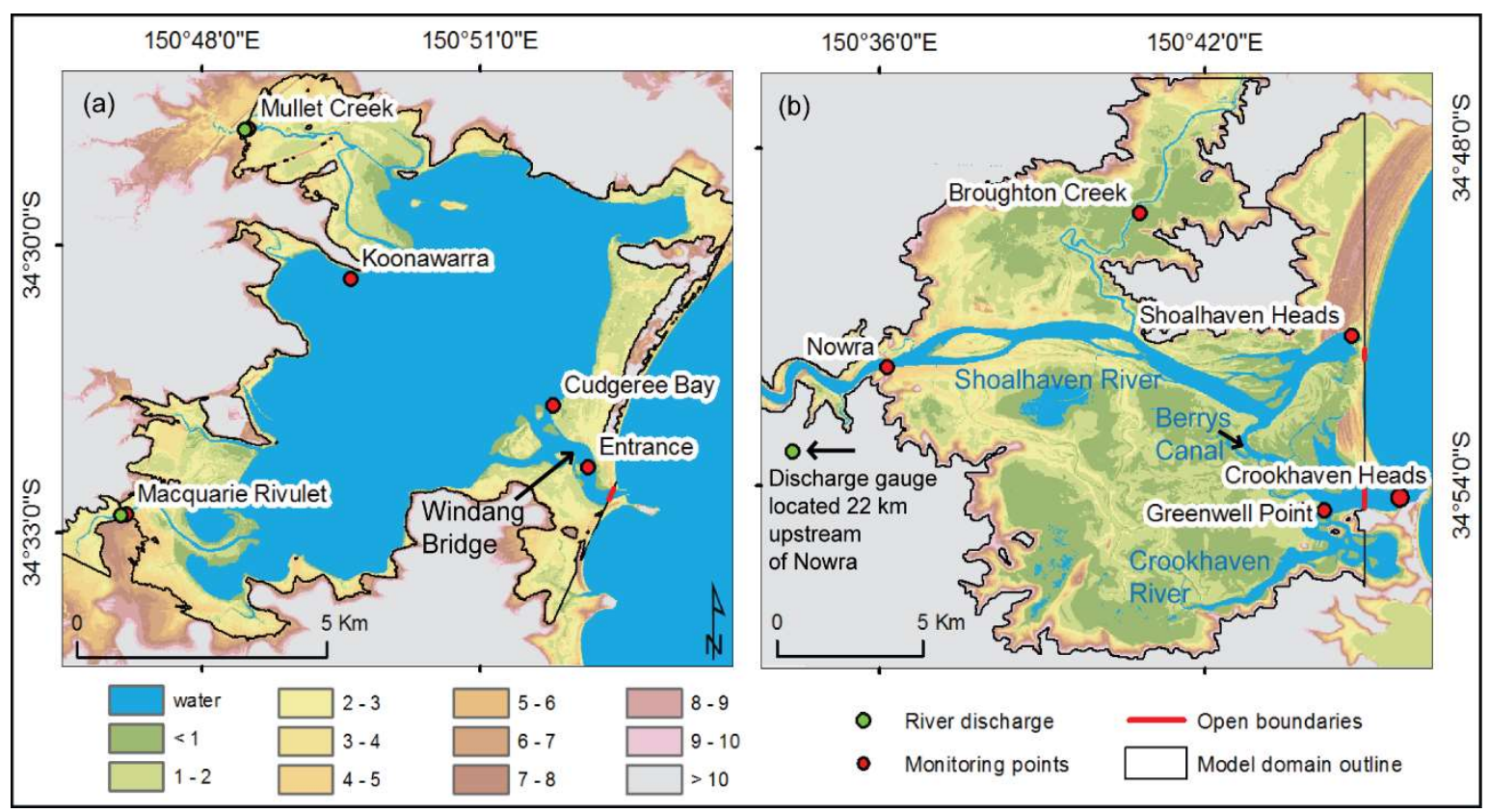

Figure 1. Topography and model setup at Lake Illawarra (a) and the Shoalhaven Estuary (b). LiDAR-derived topographic data of the floodplain is presented in $\mathrm{m}$ Australian height datum (AHD). Hydrodynamic model domains (black outline), open boundaries (red lines), river discharge locations (green dots) and monitoring points (red dots).

\section{Materials and Methods}

\subsection{Input Data}

Estuarine plain topography was determined from airborne LiDAR (Light Detection and Ranging) digital elevation data relative to AHD with a spatial resolution of $5 \mathrm{~m}$ (http://www.ga.gov.au/ elvis/). Bathymetric data consisting of point measurements vertically referenced to AHD were downloaded from NSW Office of Environment and Heritage (OEH; http: / / www.environment.nsw.gov. $\mathrm{au}$ /estuaries/list.htm). Water level measurements at $15 \mathrm{~min}$ intervals for tidal gauges at the entrance to Lake Illawarra and along the Shoalhaven Estuary were provided for 1 year (June 2015 to July 2016) by OEH (distributed through Manly Hydraulics Laboratory). The entrance gauge, in Lake Illawarra, and Crookhaven Heads gauge, in the Shoalhaven Estuary, recorded a storm event in June 2016, which was used for the simulation of storm surge and compound flooding conditions. Discharge measurements for compound flooding simulations were provided at $15 \mathrm{~min}$ intervals for the Shoalhaven River at Tallowa Dam, which is located approximately $68 \mathrm{~km}$ upstream of the coast, and Macquarie Rivulet by NSW Water. Wind data of the same storm event measured at Port Kembla $(5 \mathrm{~km}$ north of Lake Illawarra) were obtained from the server of the Bureau of Meteorology (http://www.bom.gov.au/ oceanography/projects/abslmp/data/). Land use data were downloaded from OEH (http: / / data. environment.nsw.gov.au/dataset/nsw-landuseac11c).

\subsection{Flood Drivers and SLR Scenarios}

Modelling of present day hydrodynamic conditions used spring-tide forcing only (approximately HHWSS), storm surge only (HHWSS plus a positive surge resulting from the inverse barometric effect and wind set-up), and combined storm surge and riverine flooding, so called compound or coincident flooding. These three simulations for each estuary were then repeated for SLR increases of $+0.4 \mathrm{~m}$ and $+0.9 \mathrm{~m}$ to run 9 simulations in total per study site. SLR scenarios were selected in relation to the lower and upper boundary of the IPCC's AR5 SLR scenarios [2] and estimates of McInnes et al. [7], 
Webb and Hennessy [33] and Zheng et al. [8] for the Australian coastline. Furthermore, values of +0.4 and $+0.9 \mathrm{~m}$ in SLR have been advocated by the NSW state government as SLR planning benchmarks.

Time series of water-level changes for the storm surge simulation were taken from gauges at the entrance of Lake Illawarra and Crookhaven Heads in the Shoalhaven Estuary (red dots in Figure 1) for the previously mentioned storm event. According to Burston et al. [34], the coastal water level of this storm event, comprising storm surge and wave run-up, had an annual reoccurrence interval (ARI) of approximately 16 years for Lake Illawarra and 50 years for the Shoalhaven Estuary. The same time series of water-level changes (1 year of record) were analysed for predicted astronomical tides using UTide package for Matlab [35] in order to create time-series data sets for spring-tide-only forcing of model boundaries. River discharge measurements of the Shoalhaven River and Macquarie Rivulet were used to create time-series of discharge for normal (prior the storm) and extreme conditions (during peak of the storm). Spring-tide and storm surge simulations used discharge datasets for normal conditions while the compound flooding simulation used the original measurements of the storm. The same approach was used to create wind datasets for calm (for tidal simulations) and storm conditions (for storm surge and compound simulations). Scenarios for SLR of $+0.4 \mathrm{~m}$ and $+0.9 \mathrm{~m}$ were constructed through linear addition of the respective value to the spring-tide and storm surge water level time-series datasets described above.

\subsection{Hydrodynamic Modelling}

All hydrodynamic simulations were carried out using the Delft3D-Flow module of the open source numerical modelling software Delft3D [36]. The model was run in depth-averaged mode (2D) to solve the unsteady shallow water equations on a rectangular grid. For more information on the Delft3D code and the underlying unsteady shallow (2D) water equations the reader is referred to the software manual of Delft3D [36]. The general model setup comprising open boundaries, discharge locations and monitoring points is illustrated for both study sites in Figure 1.

Modelling at Lake Illawarra used a spatial resolution of $15 \mathrm{~m}$, an open boundary at the entrance gauge and two river discharge locations at the tributaries Macquarie Rivulet and Mullet Creek. The modelling setup for tidal simulations at the Shoalhaven Estuary used one open boundary at Crookhaven Heads that was forced with data from the respective tidal gauge. Simulations of storm surge and compound flooding used an additional open boundary at Shoalhaven Heads, because the intermittent entrance opened in response to the simulated storm event in June 2016. All simulations at the Shoalhaven Estuary used a spatial resolution of $25 \mathrm{~m}$. Spatially varying bottom friction with respect to different land use types was defined using Manning's friction coefficients taken from literature [37-39]. Adaptation measures such as tidal gates were only considered by their representation within the digital elevation data. Bathymetry and topography were assumed to be constant in time.

Model setups for both estuaries were validated for the previously mentioned storm event in June 2016. Therefore, observational data such as satellite imagery, aerial photographs, tidal gauges and water level logger measurements were used to compare against modelling results $[17,18]$. Table 1 summarises statistics derived from comparing modelled and observed water levels for several gauges shown in Figure 1.

Table 1. Statistical measures derived from comparison of modelled and observed water levels for the present-day storm surge simulation at Lake Illawarra and the Shoalhaven Estuary.

\begin{tabular}{cccccc}
\hline \multicolumn{2}{c}{ Lake Illawarra } & \multicolumn{3}{c}{ Shoalhaven Estuary } \\
\hline Tide Gauge & $\mathbf{r}^{\mathbf{2}}$ & rmse (m) & Tide Gauge & $\mathbf{r}^{\mathbf{2}}$ & rmse (m) \\
\hline Entrance & 0.97 & 0.12 & Greenwell Point & 0.98 & 0.09 \\
Cudgegree Bay & 0.98 & 0.12 & Shoalhaven Heads & 0.98 & 0.15 \\
Koonawarra & 0.97 & 0.14 & Nowra & 0.99 & 0.18 \\
Macquarie R. & 0.94 & 0.21 & & & \\
\hline
\end{tabular}


At both sites, modelled and observed water levels correlated very well, whereas root mean square errors (rmse) were reasonably low, suggesting that the presented model setup is able to replicate inundation processes within the estuaries. This is further demonstrated by minor model underestimation of maximum current velocities $(1 \mathrm{~cm})$ at the Shoalhaven Estuary [17]. The reasonably good match between observed (satellite imagery and aerial photographs) and modelled inundation extents reinforces the accuracy of the modelling setup $[17,18]$. However, the absence of suitable data to validate current velocities at Lake Illawarra limits the credibility of velocity modelling and at this site and in consequence those results should be interpreted with caution.

Maps of maximum inundation extents were calculated in a GIS from the number of inundated pixels and known pixel dimensions. Outputs of maximum inundation depths per grid cell were used to calculate the average inundation depth (mean) for each simulation. Outputs of maximum inundation depth per computational grid cell were reclassified in a GIS into intervals of $0.25 \mathrm{~m}$ to enhance the comparison of modelling scenarios. Changes in tidal range were determined by comparison of maximum difference between consecutive high and low water at monitoring points indicated in Figure 1.

\section{Results}

\subsection{Inundation Extents and Depths}

Modelled maximum inundation extents using spring-tide, storm surge and compound flood drivers under different SLR scenarios for Lake Illawarra and the Shoalhaven Estuary are presented in Table 2. At Lake Illawarra, modelling for present-day conditions predicted an inundation extent of $1.5 \mathrm{~km}^{2}$ for spring-tide forcing, $4.3 \mathrm{~km}^{2}$ for storm surge $(+186 \%)$ and $5.1 \mathrm{~km}^{2}$ for compound flooding $(+240 \%)$. Adding SLR of $+0.4 \mathrm{~m}$ increased the inundation extent for all flood drivers by $60-90 \%$, while differences in inundation extent between the drivers remained distinct. Simulations using a SLR of $+0.9 \mathrm{~m}$ demonstrated another increase in inundation extent for all drivers by $50-100 \%$. Differences in inundation extent between flood drivers remained considerable $(100 \%$ between spring-tide and storm surge simulations), even though differences between storm surge and compound flooding decreased with an increase in sea level. Figure 2 presents spatial differences in inundation extents for spring-tidal simulations of present conditions and SLR scenarios at Lake Illawarra and the Shoalhaven Estuary. Spatial differences in inundation extents for storm surge and compound flooding simulations of present conditions and SLR scenarios at both estuaries are presented in Appendix A (Figure A1). At Lake Illawarra, the greatest increases in inundation extent were located around Mullet Creek, Macquarie Rivulet and the entrance of the lake.

Table 2. Modelled inundation extents and rounded average inundation depths at Lake Illawarra and Shoalhaven Estuary for flood driver and scenario combinations. SLR: Sea-level rise.

\begin{tabular}{|c|c|c|c|c|c|c|}
\hline \multirow[t]{2}{*}{$\begin{array}{l}\text { Study Site and } \\
\text { Flood Driver }\end{array}$} & \multicolumn{2}{|c|}{ Present } & \multicolumn{2}{|c|}{$+0.4 \mathrm{~m} \mathrm{SLR}$} & \multicolumn{2}{|c|}{$+0.9 \mathrm{~m} \mathrm{SLR}$} \\
\hline & $\begin{array}{c}\text { Inundation } \\
\text { Extent } \\
\left(\mathbf{k m}^{2}\right)\end{array}$ & $\begin{array}{c}\text { Average } \\
\text { Inundation } \\
\text { Depth }(\mathrm{m})\end{array}$ & $\begin{array}{c}\text { Inundation } \\
\text { Extent } \\
\left(\mathrm{km}^{2}\right)\end{array}$ & $\begin{array}{c}\text { Average } \\
\text { Inundation } \\
\text { Depth (m) }\end{array}$ & $\begin{array}{c}\text { Inundation } \\
\text { Extent } \\
\left(\mathrm{km}^{2}\right)\end{array}$ & $\begin{array}{c}\text { Average } \\
\text { Inundation } \\
\text { Depth (m) }\end{array}$ \\
\hline \multicolumn{7}{|l|}{ L. Illawarra } \\
\hline tide & 1.5 & 0.4 & 2.9 & 0.7 & 5.8 & 0.9 \\
\hline storm-tide & 4.3 & 0.8 & 7.3 & 0.9 & 11.6 & 1.1 \\
\hline compound & 5.1 & 0.8 & 8.1 & 0.9 & 12.1 & 1.1 \\
\hline \multicolumn{7}{|l|}{ Shoalhaven } \\
\hline tide & 32 & 0.5 & 62 & 0.6 & 89 & 0.9 \\
\hline storm-tide & 54 & 0.7 & 78 & 1.0 & 100 & 1.4 \\
\hline compound & 75 & 0.8 & 91 & 1.1 & 104 & 1.6 \\
\hline
\end{tabular}




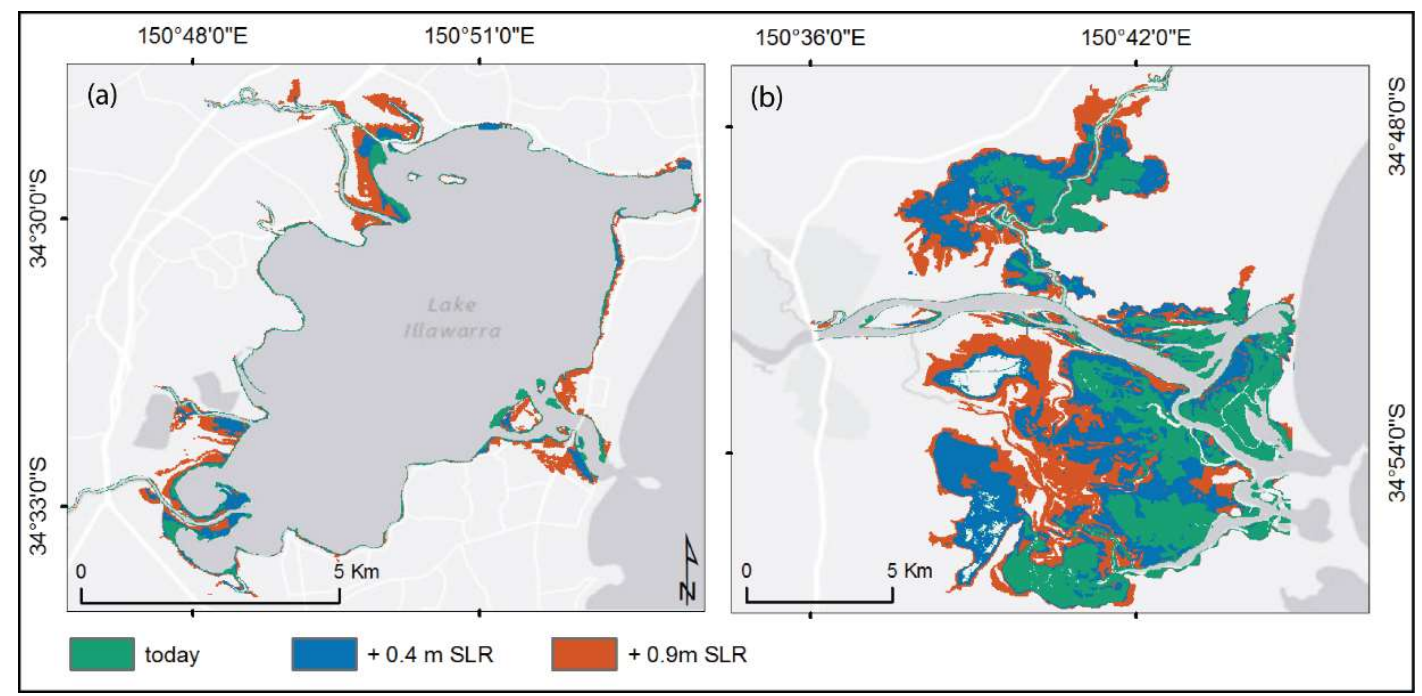

Figure 2. Maximum inundation extents of spring-tidal simulations for present conditions and SLR scenarios at Lake Illawarra (a) and the Shoalhaven Estuary (b).

At the Shoalhaven Estuary, spring-tidal forcing with today's sea level inundated an area of $32 \mathrm{~km}^{2}$, whereas the storm surge simulation inundated an area of $54 \mathrm{~km}^{2}(+70 \%)$ and compound flooding an area of $75 \mathrm{~km}^{2}(+135 \%)$. These differences in inundation extents between flood drivers decreased under $+0.4 \mathrm{~m} \mathrm{SLR}$, as the spring-tide inundated an area of $62 \mathrm{~km}^{2}$, the storm surge an area of $78 \mathrm{~km}^{2}(+25 \%)$ and the compound flooding an area of $91 \mathrm{~km}^{2}(+45 \%)$. An increase in sea level by $+0.9 \mathrm{~m}$ decreased differences in inundation extents between drivers even more. Spring-tidal forcing inundated an area of $89 \mathrm{~km}^{2}$, whereas the storm surge and compound simulations inundated areas of $100 \mathrm{~km}^{2}(+12 \%)$ and $104 \mathrm{~km}^{2}(+17 \%)$ respectively. Inundation extents of spring-tidal simulations expanded mainly in the western part of the Crookhaven and Broughton Creek floodplain (Figure 2).

Average inundation depths at Lake Illawarra increased by approximately $0.1 \mathrm{~m}$ for the $+0.4 \mathrm{~m}$ SLR simulations of storm surge and compound flooding and by $0.3 \mathrm{~m}$ for the spring-tidal simulation (Table 2). Simulations of $+0.9 \mathrm{~m}$ SLR for storm surge and compound flooding increased average inundation depths by $0.3 \mathrm{~m}$, whereas those from the spring-tidal simulation increased by $0.5 \mathrm{~m}$.

Average inundation depths of storm surge and compound flooding under $+0.4 \mathrm{~m}$ SLR at the Shoalhaven Estuary increased at a faster rate $(0.3 \mathrm{~m})$ than at Lake Illawarra, but were slower for spring-tidal simulations ( $+0.1 \mathrm{~m}$ for $+0.4 \mathrm{~m}$ SLR). A similar pattern was observed for simulations of $+0.9 \mathrm{~m} \mathrm{SLR}$, as inundation depths for storm surge and compound flooding increased by $0.7-0.8 \mathrm{~m}$, whereas those for spring-tidal simulation were comparable to results at Lake Illawarra $(+0.4 \mathrm{~m})$.

Figure 3 illustrates the distribution of maximum inundation depths across the floodplain of Lake Illawarra and the Shoalhaven Estuary in classes of $0.25 \mathrm{~m}$ intervals for spring-tidal (red lines) and storm surge simulations (blue lines), as well as SLR scenarios (dashed and dotted) for both drivers. At Lake Illawarra, the areas per inundation depth class increased with SLR, but the distribution between classes remained similar. The inundation depth classes smaller than $0.5 \mathrm{~m}$ remained the dominating ones for all displayed simulations except for the storm surge simulation with $+0.9 \mathrm{~m}$ SLR. In contrast, at the Shoalhaven Estuary inundation depths across the floodplain appear to shift from approximately $0.5-0.75 \mathrm{~m}$ towards $1.25 \mathrm{~m}$ (tide $+0.9 \mathrm{~m}$ SLR) and even 1.5-2 m (storm surge $+0.9 \mathrm{~m}$ SLR) with SLR. 


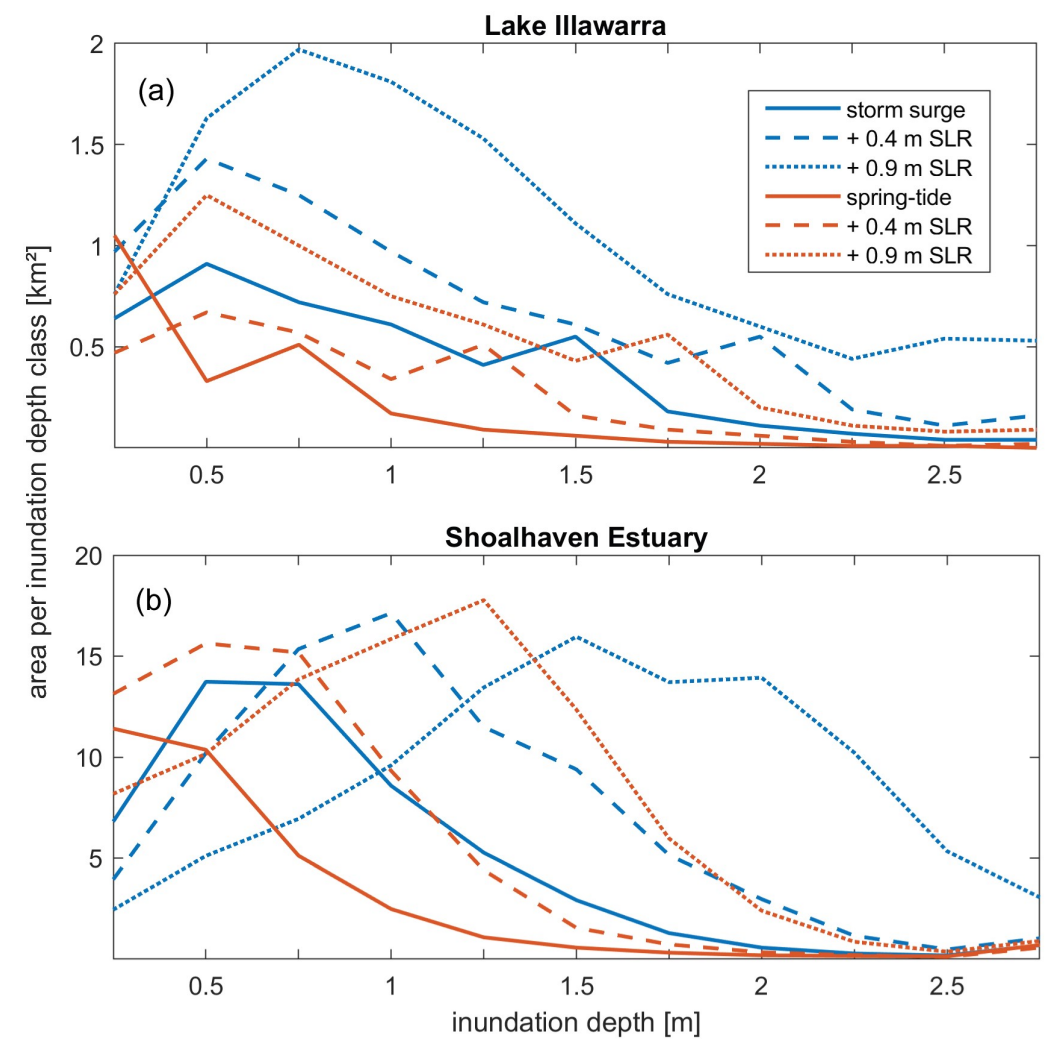

Figure 3. Distribution of maximum inundation depths in $0.25 \mathrm{~m}$ intervals across the floodplain of Lake Illawarra (a) and the Shoalhaven Estuary (b) for simulations of spring-tide (red) and storm surge (blue) in combination with present sea level as well as SLR of $+0.4 \mathrm{~m}$ and $+0.9 \mathrm{~m}$. Note the difference in vertical scale due to the different size of the floodplains.

\subsection{Hydrodynamics}

Simulated water levels for spring-tidal conditions and SLR scenarios at Lake Illawarra are presented in Figure 4. Note that mean tidal level at both estuaries is elevated by approximately $0.25 \mathrm{~m}$ during simulation time due to the highest spring tides (summer solistice) of the year. Results indicate at all four monitoring locations inside Lake Illawarra an increase of approximately $0.4 \mathrm{~m}$ in MSL during simulation, which is independent of the applied SLR scenario and likely relates to spring-tidal pumping.

Changes in tidal range were very consistent between the monitoring points in Cudgeree, Koonawarra, Macquarie Rivulet and Mullet Creek. During present spring-tidal conditions the tidal range at the respective locations has a maximum of $0.25 \mathrm{~m}$, except for the monitoring points in Mullet Creek, which is presently not subject to tides due to its upstream location behind a small weir. Adding SLR of $+0.4 \mathrm{~m}$ to tidal simulations increases the tidal range at all places by $0.1 \mathrm{~m}$ (going to be $0.35 \mathrm{~m}$ ). The simulation for SLR of $+0.9 \mathrm{~m}$ demonstrated an increase of tidal range by $0.25 \mathrm{~m}$ (going to be $0.5 \mathrm{~m}$ ). Similar increases in tidal range due to SLR were also observed for storm surge and compound flooding simulations. Comparison of tidal ranges at different locations in the entrance channel showed that the tide is mainly attenuated after is passes Windang Bridge, where the channel widens and the water depth decreases. 

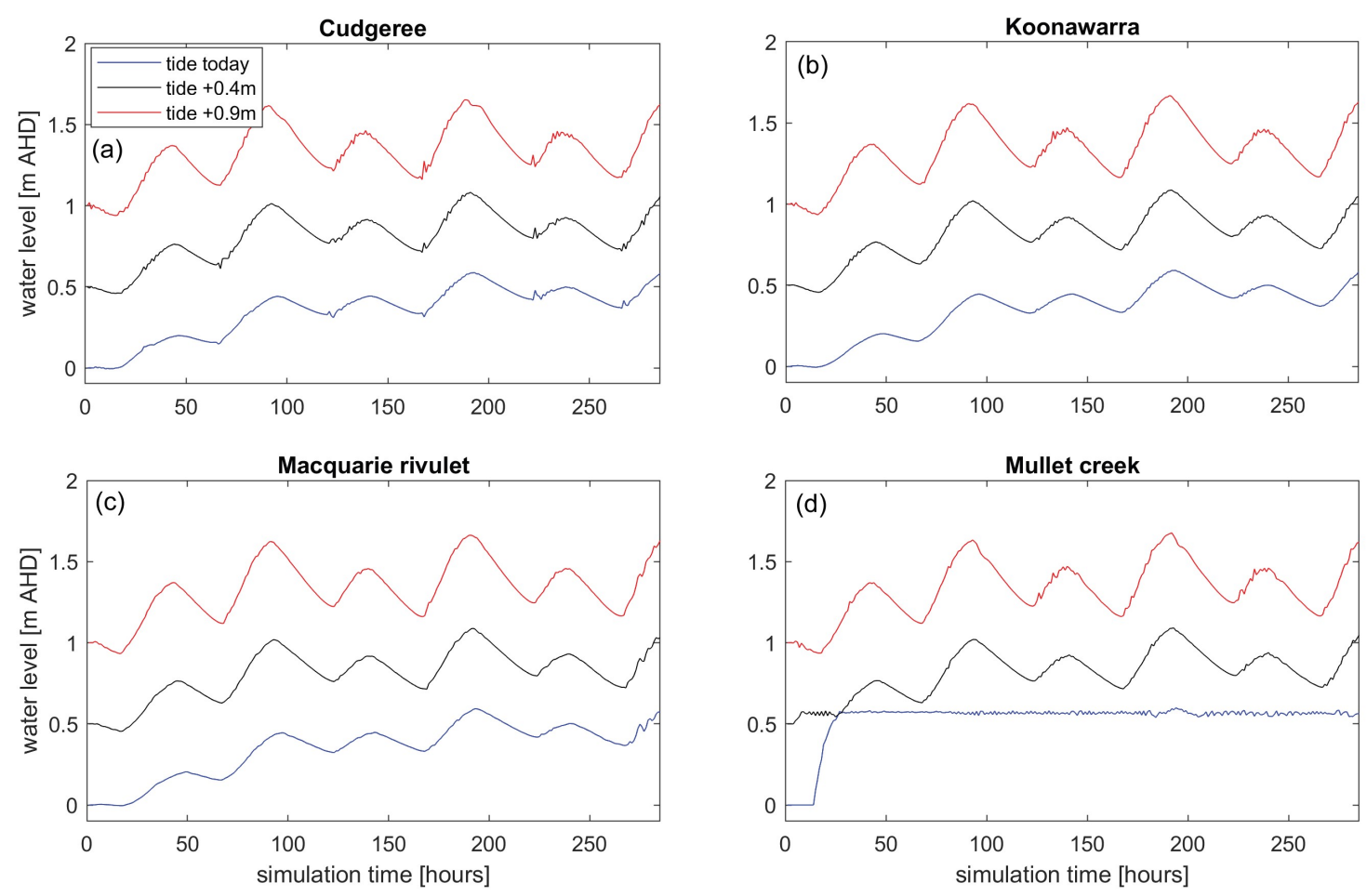

Figure 4. Simulated water levels for spring-tidal conditions and SLR scenarios over 6 tidal cycles at Cudgeree (a), Koonawarra (b), Macquarie Rivulet (c), and Mullet Creek (d) in Lake Illawarra. Mullet Creek monitoring point is not subject to tides at present sea level conditions due to its upstream location behind a tidal weir.

Figure 5 presents simulated water levels for spring-tidal conditions and SLR scenarios at the Shoalhaven Estuary. The maximum tidal range at Greenwell Point remained stable at $1.5 \mathrm{~m}$ independent of SLR scenario. Tidal range increased slightly further upstream. At Shoalhaven Heads, tidal range increased just slightly for SLR of $+0.4 \mathrm{~m}$ and by $0.1 \mathrm{~m}$ for SLR of $+0.9 \mathrm{~m}$. At Nowra, tidal range increased by $0.1 \mathrm{~m}$ for SLR of $+0.4 \mathrm{~m}$ and by $0.2 \mathrm{~m}$ for SLR of $+0.9 \mathrm{~m}$. Broughton Creek was the only monitoring location where tidal range decreased. While the maximum tidal range for present-day conditions was $0.95 \mathrm{~m}$, it decreased to $0.8 \mathrm{~m}$ for SLR of $+0.4 \mathrm{~m}$ and to $0.5 \mathrm{~m}$ for SLR of $+0.9 \mathrm{~m}$. The steady increase in MSL during spring-tidal simulation with $+0.9 \mathrm{~m}$ SLR further indicates tidal pumping during spring tides at Broughton Creek.

Modelling of depth-averaged current velocities indicated no considerable changes at locations inside the lake, but monitoring in the entrance channel at Windang Bridge (Figure 6a) indicated an increase by $0.3 \mathrm{~m} / \mathrm{s}$ for SLR of $+0.4 \mathrm{~m}$ (to $1.6 \mathrm{~m} / \mathrm{s}$ ) and an increase by $0.9 \mathrm{~m} / \mathrm{s}$ for SLR of $+0.9 \mathrm{~m}$ (to $2.1 \mathrm{~m} / \mathrm{s}$ ). Furthermore, Figure 6a illustrates the diurnal inequality in the tide and comparatively stronger flood current velocities, which seem to intensify with SLR. Peak current velocities in each scenario simulation correspond to rising tide towards the higher high water of the tidal cycle. 

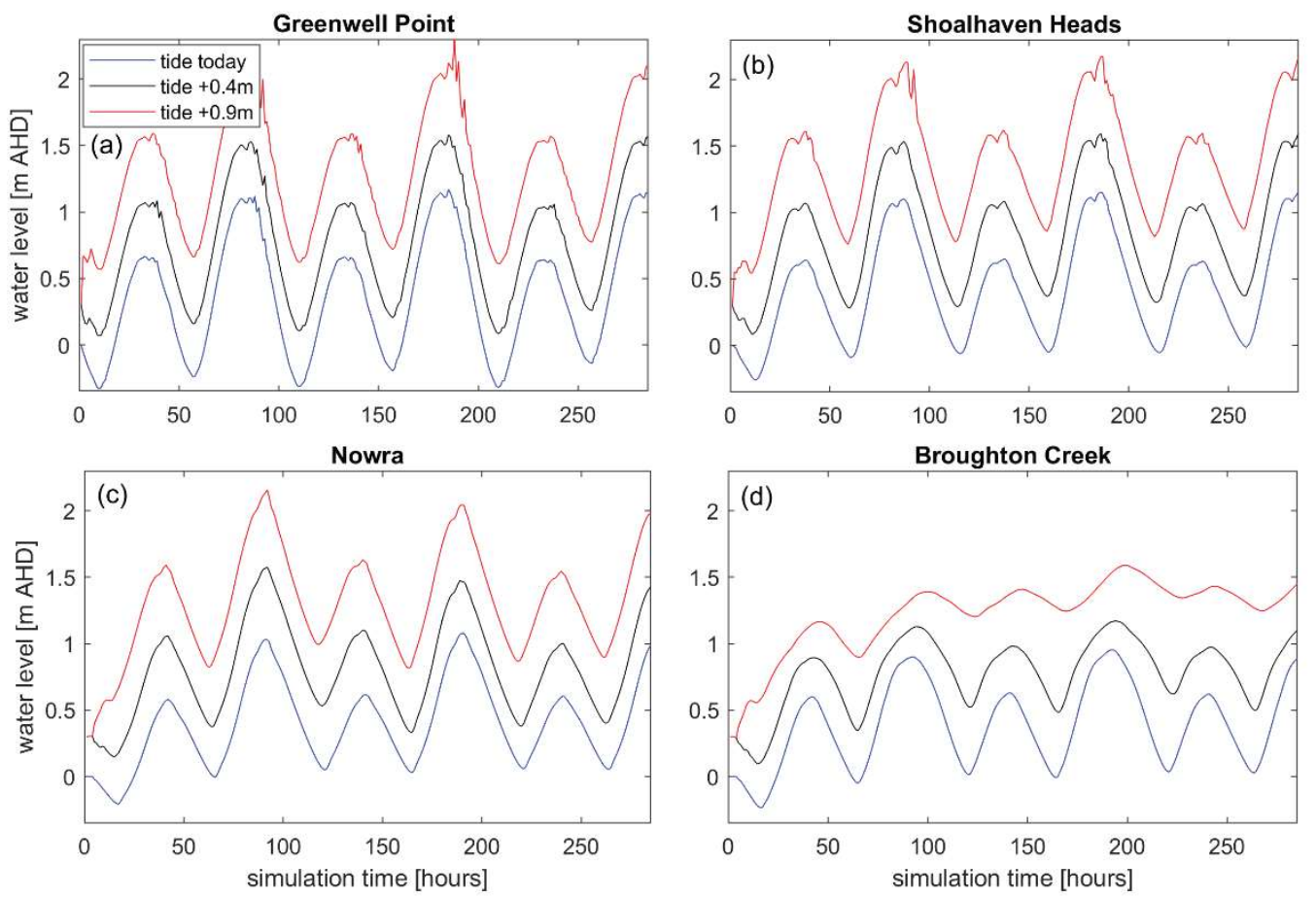

Figure 5. Simulated water levels for spring-tidal conditions and SLR scenarios over 6 tidal cycles at Greenwell Point (a), Shoalhaven Heads (b), Nowra (c), and Broughton Creek (d) in the Shoalhaven Estuary.

At the Shoalhaven Estuary depth-averaged current velocities only increased slightly in the main channel at Berrys Canal $(0.1 \mathrm{~m} / \mathrm{s}$ for $+0.4 \mathrm{~m}$ and $+0.9 \mathrm{~m}$ SLR). Changes at Nowra were just marginal. However, the lower Broughton Creek displayed a doubling of maximum current velocity (to then $0.3 \mathrm{~m} / \mathrm{s}$ ) for SLR of $+0.4 \mathrm{~m}$ and further strengthening during simulations of $+0.9 \mathrm{~m}$ SLR (to then approximately $0.5 \mathrm{~m} / \mathrm{s}$ ) (Figure $6 \mathrm{~b}$ ). The monitoring of depth-averaged velocity in Figure $6 \mathrm{~b}$ further shows the diurnal inequality in the tide and flood current dominance as observed already in the entrance channel of Lake Illawarra. The eastern Crookhaven River displayed also a doubling of maximum current velocities to $0.3 \mathrm{~m} / \mathrm{s}$ for SLR of $+0.9 \mathrm{~m}$.
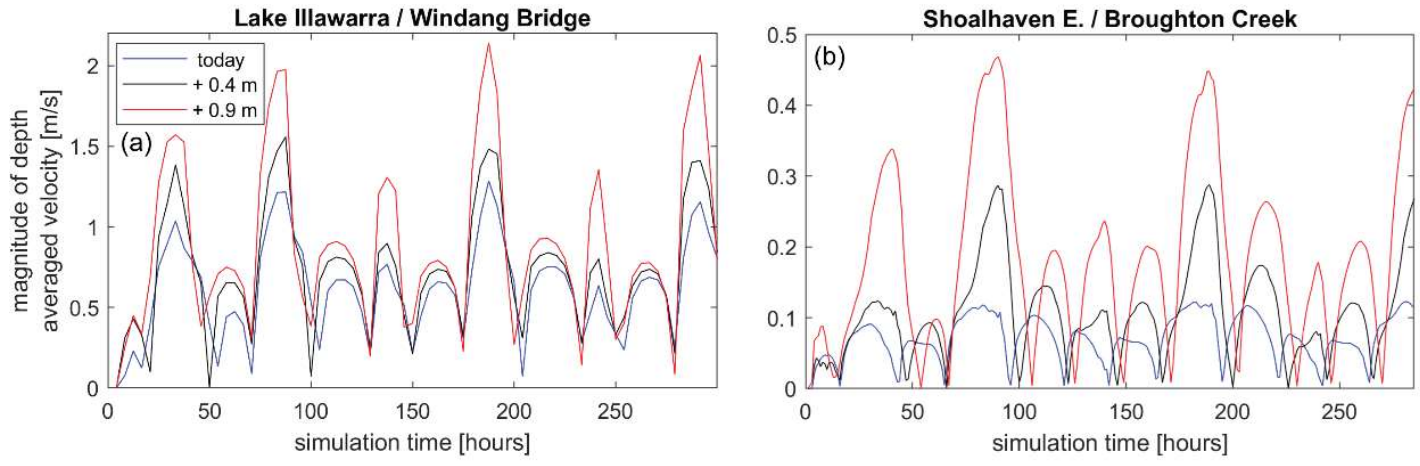

Figure 6. Simulated magnitude of depth-averaged current velocities for spring-tidal conditions and SLR scenarios over 6 tidal cycles at Windang Bridge in Lake Illawarra (a) and Broughton Creek in the Shoalhaven Estuary (b). 


\section{Discussion}

\subsection{Changes in Inundation Extents and Depths}

The comparison of modelled inundation extents and depths due to different flood drivers and SLR conditions, whenever these will happen, revealed several differences between the two estuaries, which are discussed hereafter. At Lake Illawarra, modelled inundation extents due to spring-tide, storm surge and compound flooding were constantly increasing at high rates due to SLR (between $50-100 \%$ ) and differences in extent between flood drivers remained distinct (e.g., 100\% between simulated spring-tide and storm surge extent for $0.9 \mathrm{~m} \mathrm{SLR}$ ). This was different at the Shoalhaven Estuary, where inundation extents were increasing at lower rates (between $20 \%$ and $100 \%$ ), especially for $+0.9 \mathrm{~m}$ SLR scenarios (between $14 \%$ and $40 \%$ ). Furthermore, differences in inundation extent between drivers became fairly small with increasing sea level (e.g., $12 \%$ between simulated spring-tide and storm surge extent for $+0.9 \mathrm{~m} \mathrm{SLR})$. These differences in response to SLR are likely related to the morphological differences between the two sites. Most of the extensive floodplains of the Shoalhaven Estuary appear to overtop during flooding and in consequence, the inundation extent between drivers does not differ greatly. In contrast, at Lake Illawarra, SLR appears to elevate the lake water level and inundates low-lying areas surrounding the lake shoreline, even though tidal range is reduced in the entrance channel. This tidal attenuation is likely influencing the differences in inundation extent observed between flood drivers as peak water levels between storm surge and spring-tide differ.

At the Shoalhaven Estuary, the extent of inundation due to spring-tides, storm surge and compound flooding may become very similar in the future, because MSL appears to reach a tipping point that enables inundation of large parts of the floodplain independently of the flooding driver. In consequence, vast areas of the Shoalhaven floodplain are likely to be submerged and become tidal if no future adaptation measures are implemented. This is also confirmed by comparatively high increases in average inundation depths for the $+0.9 \mathrm{~m}$ SLR scenarios. As inundation extents did not increase greatly between $+0.4 \mathrm{~m}$ and $+0.9 \mathrm{~m}$ SLR simulations, the additional floodwater added up nonlinearly in the vertical dimension. Figure 3 illustrates this shift from spring-tidal inundation depths being mainly between 0.5 and $0.75 \mathrm{~m}$ at present conditions, towards $1.5 \mathrm{~m}$ for future conditions. In consequence, floodplains in estuaries similar to the Shoalhaven Estuary may see considerable changes in the landscape through migration of tidal wetlands such as saltmarshes or mangroves. The broad floodplains may provide accommodation space for wetland migration [40], whereas estuaries with narrow floodplains or highly urbanised floodplains may prohibit the migration of tidal wetlands (coastal squeeze) and thus cause a loss of these valuable ecosystems [41,42]. Floodplain management in mature estuaries should consider the above and allow floodwater to enter low-lying areas in order to reduce the height of water levels in the channelised river and provide potential accommodation space for the migration and colonisation of tidal wetlands and their ecosystem services such as the mitigation of coastal flood risk [43,44].

In contrast, at Lake Illawarra, SLR caused considerable increases in inundation extent even for simulations of $+0.9 \mathrm{~m}$ SLR. It appears that floodwater spreads horizontally, and in consequence average inundation depths increased at a smaller rate than observed in the Shoalhaven Estuary. Generally, changes in inundation depth in response to SLR in estuaries appear to be nonlinear. This was demonstrated by the presented differences in inundation depth between flood drivers and SLR scenarios at the two study sites. Our results corroborate findings by Yang et al. [24] who showed average water depth to increase linearly at roughly half of the SLR rate in the Snohomish River estuary in the United States. Estuarine geomorphology is too complex to come up with a universal formula as to how estuaries respond to SLR. Nevertheless, there appears to be a relationship between changes in inundation extent and depth due to SLR for estuaries: where inundation extents are increasing considerably, inundation depths increase at a comparatively slow rate as floodwater spreads horizontally. If inundated areas expand just insignificantly, inundation depths are going to increase at a similar rate to SLR. Similar findings were presented by Bilskie et al. [45]. 
The different responses of the estuaries to SLR can be further interpreted by investigating the floodplain elevation of the respective sites. Figure 7 shows the distribution of estuarine floodplain elevations ( 0 to $10 \mathrm{~m}$ AHD) in classes of $0.5 \mathrm{~m}$ at Lake Illawarra and the Shoalhaven Estuary. Areas given per elevation class were normalised to scale the data.

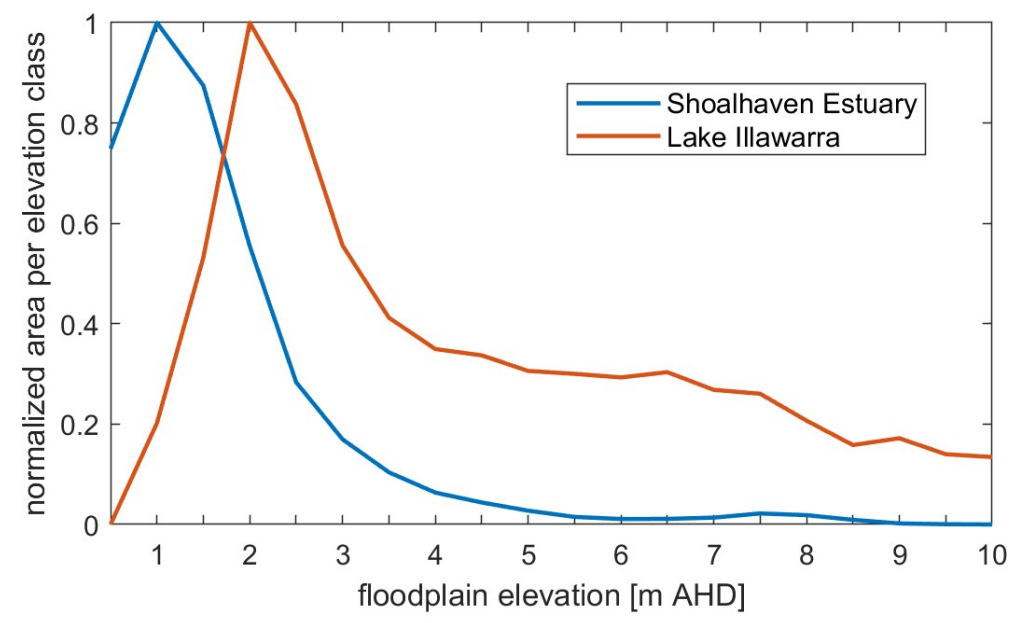

Figure 7. Distribution of estuarine floodplain elevation (0-10 m AHD) for Lake Illawarra and the Shoalhaven Estuary. Floodplain elevation was reclassified to intervals of $0.5 \mathrm{~m}$ and the corresponding areas per class normalised to scale the data.

Whereas the majority of low-lying areas in the Shoalhaven Estuary are below $2 \mathrm{~m}$ AHD and consequently subject to flooding during peak water levels higher than $2 \mathrm{~m}$ AHD (the peak high water during spring-tidal conditions with $0.9 \mathrm{~m}$ SLR was $2.1 \mathrm{~m}$ AHD at the entrance), the floodplain of Lake Illawarra is more heterogeneous with the majority of low lying areas being located between 1.5 and $2.5 \mathrm{~m}$ AHD. The distribution of floodplain elevation may contribute to understanding why inundation depths increase more rapidly in the Shoalhaven Estuary and why differences between inundation extents resulting from spring-tide, storm surge and compound flooding are more pronounced in Lake Illawarra. Data on floodplain elevation may be used to identify the most vulnerable estuarine systems and their tipping points as has been suggested by Rogers and Woodroffe [26] who recommend using geomorphology and elevation as indicators for vulnerability of estuaries to coastal and flood hazards. The Shoalhaven Estuary floodplains, for example, appear to be mostly inundated if water levels are higher than $2 \mathrm{~m}$ AHD. If the peak water level exceeds this tipping point (independently of the flood driver causing it), the extent of inundation increases only marginally, whereas inundation depths are likely to increase considerably.

\subsection{Hydrodynamic Response to SLR}

Changes in hydrodynamic parameters such as tidal range and current velocity differed between the two estuaries. Lake Illawarra displayed a doubling of tidal range for $0.9 \mathrm{~m}$ SLR at locations inside the estuary that most likely relates to decreased friction in the entrance channel and an increase in tidal prism due to the increase in MSL. As the entrance channel has comparatively steep banks, spreading of floodwater is restricted and thus leads to an increased tidal prism and tidal range in Lake Illawarra. Similar findings have been observed by Watterson et al. [22], who analysed the hydraulic response of Lake Macquarie to rising sea levels. An increase in tidal energy is also reflected in the modelled depth-averaged current velocities at Windang Bridge in the entrance channel of Lake Illawarra, which was shown to increase by $75 \%$. The modelled velocities align well with observations by Wiecek et al. [46], but are limited in the sense that bathymetric conditions in the entrance channel are assumed to be static. As the entrance channel is subject to ongoing scouring [47], increases in tidal range are likely to be higher than those presented in this study. Significant increases in current velocity 
may even trigger additional erosion in the entrance channel of Lake Illawarra. These changes indicate how human modification has changed the estuarine system and also influences its future.

Tidal ranges in the Shoalhaven Estuary were demonstrated to increase only marginally within the Shoalhaven River, which most likely relates to the overtopping of floodwater onto the floodplain. The tidal pumping and increase in current velocity by more than $200 \%$ observed in Broughton Creek indicates that parts of the Shoalhaven Estuary floodplains may revert to becoming tidal in the future. Differences between the ebb and flow velocities displayed in Figure $6 \mathrm{~b}$ resulting from variation in channel geometry over a tidal cycle may explain why tidal pumping is occurring in the constricted Broughton Creek in the future [31].

The modelling results of hydrodynamic response to SLR for Lake Illawarra and the Shoalhaven Estuary match well with recent studies by Lee et al. [12] and Du et al. [13]. Both studies suggested that tidal ranges may increase in those estuaries that are characterised by steep channel banks and that tidal ranges may remain unchanged or even decrease in estuaries that are characterised by broad floodplains, which may act as a sink for tidal energy. This kind of differentiation is very similar to estuarine characteristics given in Roy et al. [25], who showed that mature estuarine systems display a channelised river and broad floodplains as opposed to immature estuarine systems that are defined by a constricted entrance channel and narrow floodplains. Therefore, such classifications could indicate how hydrodynamics in certain estuaries may respond to SLR. This relation to estuarine geomorphology is of great importance as the southeast coast of Australia has at least 10 estuaries with similar geomorphological characteristics to Lake Illawarra and 25 estuaries similar to the Shoalhaven Estuary [25]. Variation in future exposure to tidal inundation for different types of estuaries in NSW was also shown by Hanslow et al. [48]. Wave-dominated estuaries in other parts of the world, such as New Zealand or South Africa, may respond in a similar way to SLR as the sites presented in this study.

Our results clearly demonstrate that estuarine response to SLR is variable and differs between estuarine environments. Nevertheless, the modelling is limited in the sense that adaptation measures such as tidal gates were only considered by their elevation (e.g., a tidal gate underneath a road is represented by the elevation of the road) and not by their functionality (one- or two-way gates). The Shoalhaven Estuary floodplain has been modified in the past 200 years of use (e.g., cleared for cattle farming, construction of Berrys Canal, construction of Tallowa Dam, etc.), and future modifications such as flow regulations or levee elevations may influence the way this estuarine system will respond to SLR. Furthermore, tidal ranges at the entrance of the estuaries were assumed to be constant in time, but tides have been shown to change in response to SLR [49-51]. For shallow areas such as the entrances of Lake Illawarra and the Shoalhaven Estuary, this could imply a SLR-induced increase or decrease in high water levels due to reduced bed friction on the shelf and changes in tidal characteristics [50] that are not considered in our estimates of SLR. Another simplification of our modelling is the assumption of a static morphology. Estuarine bathymetry and morphology are likely to adjust to SLR through processes such as erosion of river banks, sedimentary infilling or scouring of channels. Floodplain morphology may change in the long term through subsidence and changes in land use may alter the spatial variations in surface roughness used for modelling. Modelling with respect to morphological and land use changes would likely improve the quality of results, but come at high computational expenses.

\section{Conclusions}

Results of this study show how variables such as inundation extent, inundation depth, tidal range and current velocities relate to each other and how they can be used to assess the response and vulnerability of estuaries of different geomorphology to SLR.

Our comparison demonstrated that there seem to be certain thresholds in floodplain elevation that may be used to identify the most vulnerable systems and estimate how inundation extents and inundation depths, as well as estuarine hydrodynamics, may change in the future. Infilled mature estuaries with broad floodplains such as the Shoalhaven Estuary will be more vulnerable to drowning, regular saltwater intrusions, and considerable increases in inundation depth for vast areas of the 
floodplain. It appears that the majority of floodplains in these systems are drowned after a certain tipping point in elevation. Immature estuaries with comparatively narrow and steep floodplains may be vulnerable to substantial changes in estuarine hydrodynamics and extensive increases in relative inundation extent due to SLR. At the Shoalhaven Estuary, an increase in inundation extent mostly affects pasture land, but at Lake Illawarra, it may seriously threaten residential areas that are presently not protected against extreme water levels, because ocean driven floods were not a major concern before mankind permanently opened the entrance of the estuary. Therefore, settlements surrounding Lake Illawarra are likely to regularly experience an increase in flooding (nuisance flooding), if no adaptation measures are implemented.

Flood risk in estuaries will change considerably in the future. At both studies sites, inundation extents and depths of spring-tidal simulations with $+0.9 \mathrm{~m}$ SLR were greater than those modelled for storm surge or compound flooding simulations at present sea level. Today's extreme water levels associated with storm events appear to be the usual conditions at spring tides, which occur naturally on several days in a month.

Our investigation demonstrates that estuarine response to SLR varies between different types of estuaries and detailed modelling is necessary to understand how systems may react to rise in MSL. The unique nature of each estuarine system does not allow for universal conclusions about how estuaries respond to SLR; however, classifications of estuarine geomorphology, as well as floodplain elevation, could indicate the nature of hydrodynamic adjustments in certain types of estuary.

Author Contributions: K.K., R.C.C. and C.D.W. conceived and designed the study; K.K. set-up the models and ran the simulations; K.K., R.C.C. and C.D.W. analysed and interpreted the results; K.K. wrote the paper with substantial input from R.C.C. and C.D.W.

Acknowledgments: This research was supported by Australian Research Council Linkage project LP130101025. K.K. expresses gratitude to Athanasios Vafeidis for supporting and supervising his MSc project. The authors thank four anonymous reviewers for their constructive reviews which helped to improve this manuscript. The provision of the following data sets is highly appreciated: bathymetric data provided by NSW Office of Environment and Heritage; water level data of tidal gauges provided by NSW Office of Environment and Heritage (distributed through Manly Hydraulics Laboratory); Land use data provided by NSW Office of Environment and Heritage; LiDAR elevation data provided by Commonwealth of Australia (Geoscience Australia); Discharge measurements provided by Water NSW.

Conflicts of Interest: The authors declare no conflict of interest.

\section{Appendix A}

Figure A1 presents spatial differences in inundation extents for storm surge and compound flooding simulations of present conditions and SLR scenarios at Lake Illawarra and the Shoalhaven Estuary. 


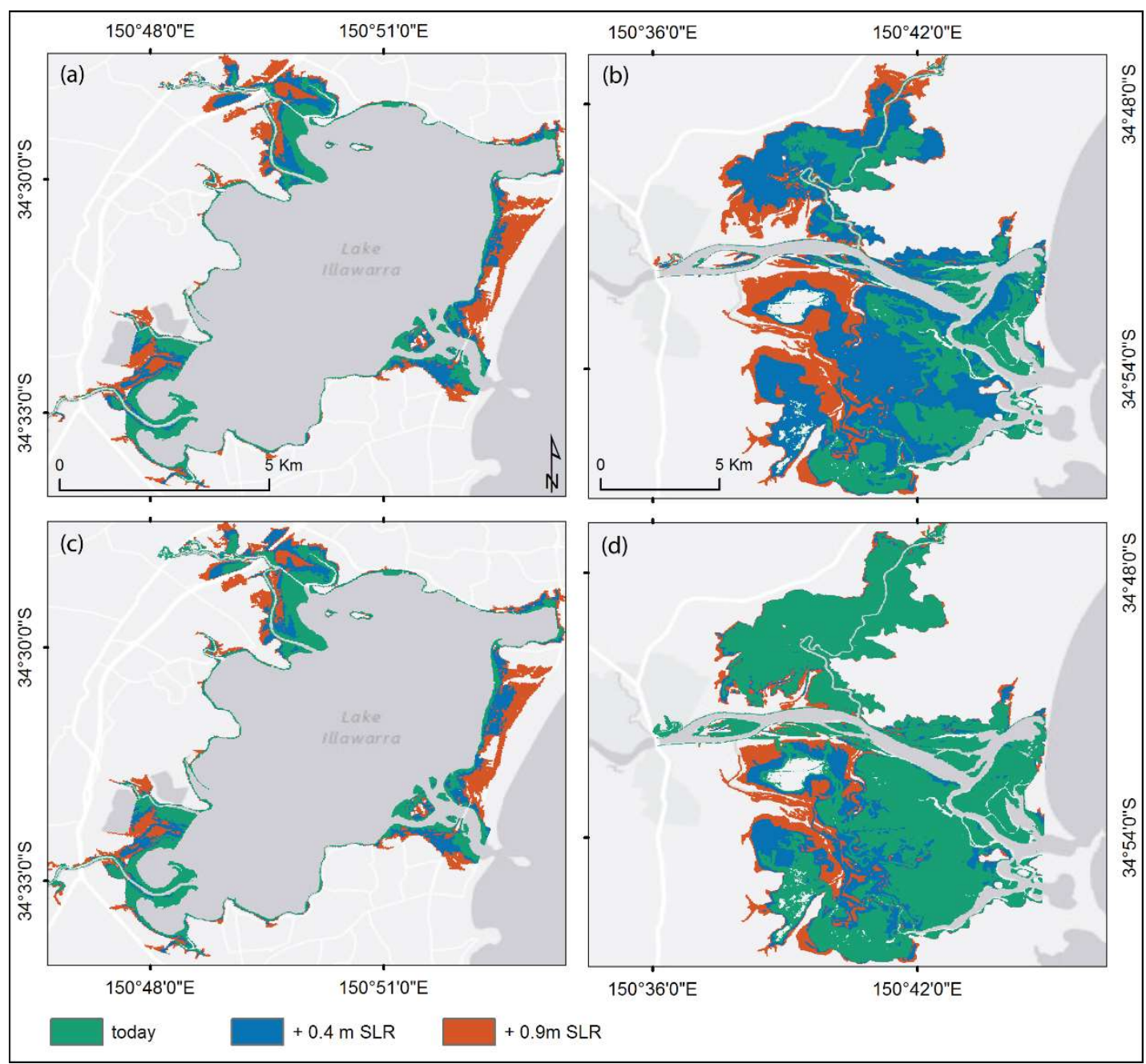

Figure A1. Maximum inundation extents of storm surge simulations for present conditions and SLR scenarios at Lake Illawarra (a) and the Shoalhaven Estuary (b), as well as the extent of compound flooding simulations $(\mathbf{c}, \mathbf{d})$ for the respective sites.

\section{References}

1. Nicholls, R.J.; Wong, P.P.; Burkett, V.R.; Codignotto, J.O.; Hay, J.E.; McLean, R.F.; Ragoonaden, S.; Woodroffe, C.D. Coastal systems and low-lying areas. In Climate Change 2007: Impacts, Adaptation and Vulnerability. Contribution of Working Group II to the Fourth Assessment Report of the Intergovernmental Panel on Climate Change; Parry, M.L., Canziani, O.F., Palutikof, J.P., Van der Linden, P.J., Hanson, C.E., Eds.; Cambridge University Press: Cambridge, UK, 2007.

2. Church, J.A.; Clark, P.U.; Cazenave, A.; Gregory, J.M.; Jevrejeva, S.; Levermann, A.; Merrifield, M.A.; Milne, G.A.; Nerem, R.S.; Nunn, P.D.; et al. Sea level change. In Climate Change 2013: The Physical Science Basis. Contribution of Working Group I to the Fifth Assessment Report of the Intergovernmental Panel on Climate Change; Stocker, T.F., Qin, D., Plattner, G.-K., Tignor, M., Allen, S.K., Boschung, J., Nauels, A., Xia, Y., Bex, V., Midgley, P.M., Eds.; Cambridge University Press: Cambridge, UK; New York, NY, USA, 2013.

3. Dangendorf, S.; Marcos, M.; Wöppelmann, G.; Conrad, C.P.; Frederikse, T.; Riva, R. Reassessment of 20th century global mean sea level rise. Proc. Natl. Acad. Sci. USA 2017, 114, 5946-5951. [CrossRef] [PubMed]

4. Nerem, R.S.; Beckley, B.D.; Fasullo, J.T.; Hamlington, B.D.; Masters, D.; Mitchum, G.T. Climate-change-driven accelerated sea-level rise detected in the altimeter era. Proc. Natl. Acad. Sci. USA 2018, 115, 2022-2025. [CrossRef] [PubMed] 
5. DeConto, R.M.; Pollard, D. Contribution of Antarctica to past and future sea-level rise. Nature 2016, 531, 591-597. [CrossRef] [PubMed]

6. Oppenheimer, M.; Alley, R.B. How high will the seas rise? Science 2016, 354, 1375-1377. [CrossRef] [PubMed]

7. McInnes, K.; Church, J.; Monselesan, D.; Hunter, J.; O'Grady, J.; Haigh, I.; Zhang, X. Information for Australian impact and adaptation planning in response to sea-level rise. Aust. Meteorol. Oceanogr. J. 2015, 65, 127-149. [CrossRef]

8. Zhang, X.; Church, J.A.; Monselesan, D.; McInnes, K.L. Sea level projections for the Australian region in the 21st century. Geophys. Res. Lett. 2017, 44, 8481-8491. [CrossRef]

9. Friedrichs, C.T.; Aubrey, D.G.; Speer, P.E. Impacts of Relative Sea-Level Rise on Evolution of Shallow Estuaries. Coast. Estuar. Stud. 1990, 38, 105-122.

10. Nicholls, R.J.; Cazenave, A. Sea-level rise and its impact on coastal zones. Science 2010, 328, 1517-1520. [CrossRef] [PubMed]

11. Geselbracht, L.L.; Freeman, K.; Birch, A.P.; Brenner, J.; Gordon, D.R. Modeled Sea Level Rise Impacts on Coastal Ecosystems at Six Major Estuaries on Florida's Gulf Coast: Implications for Adaptation Planning. PLoS ONE 2015, 10, e0132079. [CrossRef] [PubMed]

12. Lee, S.B.; Li, M.; Zhang, F. Impact of sea level rise on tidal range in Chesapeake and Delaware Bays. J. Geophys. Res. Oceans 2017, 122, 3917-3938. [CrossRef]

13. Du, J.; Shen, J.; Zhang, Y.J.; Ye, F.; Liu, Z.; Wang, Z.; Wang, Y.P.; Yu, X.; Sisson, M.; Wang, H.V. Tidal Response to Sea-Level Rise in Different Types of Estuaries: The Importance of Length, Bathymetry, and Geometry. Geophys. Res. Lett. 2018, 45, 227-235. [CrossRef]

14. Moftakhari, H.R.; AghaKouchak, A.; Sanders, B.F.; Matthew, R.A. Cumulative hazard: The case of nuisance flooding. Earth's Future 2017, 5, 214-223. [CrossRef]

15. Ikeuchi, H.; Hirabayashi, Y.; Yamazaki, D.; Muis, S.; Ward, P.J.; Winsemius, H.C.; Verlaan, M.; Kanae, S. Compound simulation of fluvial floods and storm surges in a global coupled river-coast flood model: Model development and its application to 2007 Cyclone Sidr in Bangladesh. J. Adv. Model. Earth Syst. 2017, 9, 1847-1862. [CrossRef]

16. Olbert, A.; Comer, J.; Nash, S.; Hartnett, M. High-resolution multi-scale modelling of coastal flooding due to tides, storm surges and rivers inflows. A Cork City example. Coast. Eng. 2017, 121, 278-296. [CrossRef]

17. Kumbier, K.; Carvalho, R.C.; Vafeidis, A.T.; Woodroffe, C.D. Investigating compound flooding in an estuary using hydrodynamic modelling: A case study from the Shoalhaven River, Australia. Nat. Hazards Earth Syst. Sci. 2018, 18, 463-477. [CrossRef]

18. Kumbier, K.; Carvalho, R.C.; Vafeidis, A.T.; Woodroffe, C.D. Comparing static and dynamic flood models in estuarine environments: A case study from southeast Australia. Estuar. Coast. Shelf Sci. 2018. submitted.

19. Poulter, B.; Halpin, P.N. Raster modeling of coastal flooding from sea level rise. Int. J. Geogr. Inf. Sci. 2008, 22, 167-182. [CrossRef]

20. Van de Sande, B.; Lansen, J.; Hoyng, C. Sensitivity of coastal flood risk assessments to digital elevation models. Water 2012, 4, 568-579. [CrossRef]

21. Passeri, D.L.; Hagen, S.C.; Medeiros, S.C.; Bilskie, M.V.; Alizad, K.; Wang, D. The dynamic effects of sea level rise on low-gradient coastal landscapes: A review. Earth's Future 2015, 3, 159-181. [CrossRef]

22. Watterson, E.K.; Burston, J.M.; Stevens, H.; Messiter, D.J. The hydraulic and morphological response of a large coastal lake to rising sea levels. In Proceedings of the 19th NSW Coastal Conference, Batemans Bay, Australia, 10-12 November 2010.

23. Prandle, D.; Lane, A. Sensitivity of estuaries to sea level rise: Vulnerability indices. Estuar. Coast. Shelf Sci. 2015, 160, 60-68. [CrossRef]

24. Yang, Z.; Wang, T.; Voisin, N.; Copping, A. Estuarine response to river flow and sea-level rise under future climate change and human development. Estuar. Coast. Shelf Sci. 2015, 156, 19-30. [CrossRef]

25. Roy, P.S.; Williams, R.J.; Jones, A.R.; Yassini, I.; Gibbs, P.J.; Coates, B.; West, R.J.; Scanes, P.R.; Hudson, J.P.; Nichol, S. Structure and function of south-east Australian estuaries. Estuar. Coast. Shelf Sci. 2001, 53, 351-384. [CrossRef]

26. Rogers, K.; Woodroffe, C.D. Geomorphology as an indicator of the biophysical vulnerability of estuaries to coastal and flood hazards in a changing climate. J. Coast. Conserv. 2016, 20, 127-144. [CrossRef]

27. Thom, B. Coastal Geomorphology in Australia; Academic Press: Sydney, Australia, 1984; ISBN 0126878803. 
28. Short, A.D.; Woodroffe, C.D. The Coast of Australia; Cambridge University Press: Melbourne, Australia, 2009; ISBN 0521873983.

29. Woodroffe, C.D.; Buman, M.; Kawase, K.; Umitsu, M. Estuarine infill and formation of deltaic plains, Shoalhaven River. Wetlands 2000, 18, 72-84.

30. MHL NSW Tidal Planes Analysis 1990-2010 Harmonic Analysis, Report MHL2053. Available online: http:/ / new.mhl.nsw.gov.au/docs/oeh/tidalplanes/mhl2053\%20OEH\%20tidal\%20planes\%20analysis\% 20final\%20report.pdf (accessed on 10 October 2017).

31. Hinwood, J.; McLean, E.; Trevethan, M. Spring Tidal Pumping. In Proceedings of the Coasts and Ports, Coastal Living-Living Coast: Australasian Conference, Adelaide, Australia, 20-23 September 2005.

32. Carvalho, R.C.; Woodroffe, C.D. Rainfall variability in the Shoalhaven River catchment and its relation to climatic indices. Water Resour. Manag. 2015, 29, 4963-4976. [CrossRef]

33. Webb, L.B.; Hennessy, K. Projections for Selected Australian Cities. Available online: https://www. climatechangeinaustralia.gov.au/media/ccia/2.1.6/cms_page_media/176/CCIA_Australian_cities_1.pdf (accessed on 14 September 2017).

34. Burston, J.; Taylor, D.; Garber, S. Contextualizing the return period of the June 2016 East Coast Low: Waves, water levels and erosion. In Proceedings of the 25th NSW Coastal Conference, Coffs Harbour, Australia, 9-11 November 2016.

35. Codiga, D.L. Unified Tidal Analysis and Prediction Using the UTide Matlab Functions, Technical Report 2011-01. Available online: http:/ / www.po.gso.uri.edu/pub/downloads/codiga/pubs/2011Codiga-UTidereport.Pdf (accessed on 20 October 2016).

36. Deltares. Delft3D-Flow. Simulation of Multi-Dimensional Hydrodynamic Flows and Transport Phenomena, Including Sediments, User Manual. Available online: https:/ / oss.deltares.nl/documents/183920/185723/ Delft3D-FLOW_User_Manual.pdf (accessed on 4 October 2016).

37. Chow, V.T. Open Channel Hydraulics; Blackburn Press: New York, NY, USA, 1959; ISBN 1932846182.

38. Fisher, K.; Dawson, H. Reducing Uncertainty in River Flood Conveyance, Roughness Review; DE-FRA/Environmental Agency Flood and Coastal Defense R\&D Program: Lincoln, UK, 2003.

39. Kaiser, G.; Scheele, L.; Kortenhaus, A.; Loevholt, F.; Roemer, H.; Leschka, S. The influence of land cover roughness on the results of high resolution tsunami inundation modelling. Nat. Hazards Earth Syst. Sci. 2011, 11, 2521-2540. [CrossRef]

40. Woodroffe, C.D. Mangrove response to sea level rise: Palaeoecological insights from macrotidal systems in northern Australia. Mar. Freshwater Res. 2018, 69, 917-932. [CrossRef]

41. Phan, L.K.; van Thiel de Vries, J.S.M.; Stive, M.J.F. Coastal mangrove squeeze in the Mekong Delta. J. Coast. Res. 2015, 31, 233-243. [CrossRef]

42. Woodroffe, C.D.; Rogers, K.; McKee, K.L.; Lovelock, C.E.; Mendelssohn, I.A.; Saintilan, N. Mangrove Sedimentation and Response to Relative Sea-Level Rise. Annu. Rev. Mar. Sci. 2016, 8, 243-266. [CrossRef] [PubMed]

43. Temmerman, S.; Meire, P.; Bouma, T.J.; Herman, P.M.J.; Ysebaert, T.; De Vriend, H.J. Ecosystem-based coastal defence in the face of global change. Nature 2013, 504, 79-83. [CrossRef] [PubMed]

44. Van Coppenolle, R.; Schwarz, C.; Temmerman, S. Contribution of Mangroves and Salt Marshes to Nature-Based Mitigation of Coastal Flood Risks in Major Deltas of the World. Estuaries Coasts 2018, 13. [CrossRef]

45. Bilskie, M.V.; Hagen, S.C.; Medeiros, S.C.; Passeri, D.L. Dynamics of sea level rise and coastal flooding on a changing landscape. Geophys. Res. Lett. 2014, 41, 927-934. [CrossRef]

46. Wiecek, D.; Regena, C.; Laine, R.; Williams, R.J. Quantifying change and impacts to Lake Illawarra from a permanent opening. In Proceedings of the 25th NSW Coastal Conference, Coffs Harbour, Australia, 9-11 November 2016.

47. Couriel, E.; Young, S.; Jayewardene, I.; McPherson, B.; Dooley, B. Case study: Assessment of the entrance stability of the Lake Illawarra Estuary. In Proceedings of the Coast and Ports 2013: Australasian Port and Harbour Conference Coasts and Ports 2013: 21st Australasian Coastal and Ocean Engineering Conference and the 14th Australasian Port and Harbour Conference, Sydney, Australia, 11-13 September 2013.

48. Hanslow, D.; Morris, B.D.; Foulsham, E.; Kinsela, M.D. A regional scale approach to assessing current and potential future exposure to tidal inundation in different types of estuaries. Sci. Rep. 2018, 8, 1-13. [CrossRef] [PubMed] 
49. Mudersbach, C.; Wahl, T.; Haigh, I.D.; Jensen, J. Trends in high sea levels of German North Sea gauges compared to regional mean sea level changes. Cont. Shelf Res. 2013, 65, 111-120. [CrossRef]

50. Idier, D.; Paris, F.; Le Cozannet, G.; Boulahya, F.; Dumas, F. Sea-level rise impacts on the tides of the European Shelf. Cont. Shelf Res. 2017, 137, 56-71. [CrossRef]

51. Pickering, M.D.; Horsburgh, K.J.; Blundell, J.R.; Hirschi, J.J.M.; Nicholls, R.J.; Verlaan, M.; Wells, N.C. The impact of future sea-level rise on the global tides. Cont. Shelf Res. 2017, 142, 50-68. [CrossRef] 